\title{
В.Н. ИвАКИН
}

\section{К ВОПРОСУ О ВВЕДЕНИИ ДВУХУРОВНЕВОЙ АДВОКАТУРЫ В РОССИИ: ПРОШЛОЕ И НАСТОЯЩЕЕ}

Ключевые слова: Двухуровневая адвокатура, правозаступничество, судебное представительство, совмещение, разделение, сближение.

При создании института присяжных поверенных в России пришлось решать довольно сложный вопрос о совмещении или, напротив, несовмещении в лице адвоката правозаступника и представителя. Термин «правозаступничество» использовался в русской юридической литературе второй половины XIX в. - начала XX в. и являлся переводом немецкого слова «Rechtsvertheidigung». Под правозаступничеством понималась юридическая помощь, выражающаяся в таких действиях, отличительная черта которых состоит в том, что они только помогают тяжущемуся в его деле, поддерживают его с юридической стороны, но не заменяют его лица в процессе, не устраняют его личной самодеятельности, ведения им дела. К данным действиям относятся, например, дача юридических советов тяжущимся, сочинение судебных бумаг для той или другой стороны, произнесение судебных речей в защиту ее и т.п. ${ }^{1}$. Никаких других обязанностей по производству дела и исполнению решения правозаступник не принимал на себя: они относились к сфере деятельности самого тяжущегося или его судебного представителя² При этом правозаступник действовал в качестве уполномоченного общества и в интересах его ${ }^{3}$.

Вместе с тем разного рода обстоятельства, например, болезнь, отлучка, занятия, могут мешать тяжущемуся вести свое дело в суде лично. Замена тяжущейся стороны другим лицом может потребоваться также ввиду отсутствия у нее дееспособности. Эта замена называется представительством

(С) Ивакин В.Н., 2012.

Кандидат юридических наук, доцент кафедры адвокатуры и нотариата Московской государственной юридической академии имени О. Е. Кутафина. [ivakin.st@mail.ru]

Мальшев К. Курс гражданского судопроизводства. Т. 1. СПб., 1874. С. 205.

2 Васьковский Е.В. Организация адвокатуры. Ч.1. СПб., 1893. С. 6.

3 Он же. Организация адвокатуры. Ч. 2. СПб., 1893. С. 9. 
и отличительная черта возникающего в связи с ним отношения заключается в том, что здесь одно лицо (представитель) действует в процессе вместо другого лица (представляемого), так что последствия его деятельности распространяются на представляемое лицо ${ }^{4}$

Судебное представительство определялось как такая замена в процессе тяжущегося другим лицом, при которой все последствия судебной деятельности представителя падают непосредственно на тяжущегося ${ }^{5}$. Судебный представитель обязан заместить тяжущуюся сторону на суде. Принимая на себя ведение дела, он получает право совершать все те действия, которые совершал бы сам тяжущийся, если бы он явился лично: он может делать признание от лица своего доверителя, подавать и получать судебные бумаги, просить о назначении или отсрочке дела, прекращать его миром, присутствовать при исполнении решения, вести дело единолично или приглашать к себе на помощь адвоката, - словом, как принято говорить, он является полным хозяином дела (dominus litis). В качестве правозаступника адвокат участвует только там, где дело идет о праве. Он по преимуществу и даже исключительно законовед, юрисконсульт, помощник стороны в процессе, между тем как судебный представитель - ходатай по делу, уполномоченный стороны, хозяин тяжбы ${ }^{6}$. Правозаступник только помогает тяжущемуся, являясь уполномоченным общества. Судебный представитель, напротив, заменяет личность тяжущегося, отождествляется вполне с нею и с ее интересами. Другими словами, первый - только патрон и покровитель стороны, а второй - ее процессуальный двойник ${ }^{7}$.

В случае его отделения от правозаступничества представительство имеет своей задачей лишь избавить тяжущегося в процессе от личного ходатайства по своему делу, от явок в суд, от собственноручной подачи разных прошений, жалоб, апелляций, от присутствия на заседаниях и от всех подобных действий, чрезвычайно затруднительных для занятого человека. Тяжущийся обращается к поверенному не потому, что нуждается в помощи специалиста, а потому, что сам не имеет времени, возможности или даже просто охоты ходить по судам. Деятельность поверенного однородна с деятельностью маклеров, агентов и других посредников и представителей, облегчающих заинтересованным лицам совершение всякого рода сделок ${ }^{8}$. Соответственно, по своей идее оно вовсе не требует ни специально-юридического образования, ни какой бы то ни было особой организации 9 .

4 Мальшев К. Указ. соч. С. 205.

5 Васьковский E. В. Организация адвокатуры. Ч. 1. С. 4.

6 Там же. С. 9

7 Васьковский Е. В. Организация адвокатуры. Ч. 2. С. 24.

8 Васьковский Е. В. Организация адвокатуры. Ч. 2. С. 143.

9 Он же. Организация адвокатуры. Ч. 1. С. 4. 
Проблема, возникшая при решении вопроса о целесообразности или нецелесообразности совмещения в одном лице правозаступника и представителя, состояла в том, что во Франции, опыт которой главным образом использовался при осуществлении Судебной реформы 1864 г. в России, существовало деление на стряпчих и адвокатов. Последние, образуя отдельное сословие, выполняли лишь функцию правозаступников и не осуществляли судебное представительство, т.е. действовали в суде как самостоятельные участники процесса, выступавшие от своего имени. Однако царское правительство беспокоило то, что «при таком устройстве...адвокаты во Франции достигли политического значения, несогласного с действительным их призванием». Поэтому было решено заимствовать опыт других государств (некоторых частей Германии, Голландии, Пьемонта, Неаполя, Греции), где, по ироническому замечанию И. В. Гессена, не было «гибельного деления на поверенных (avoués) и адвокатов» ${ }^{10}$.

Вместе с тем вопрос о соединении или несоединении в одном лице правозаступника и поверенного имел не только политическое значение. Так, горячим сторонником разделения в России этих профессий являлся Е. В. Васьковский, призывавший царское правительство немедленно отказаться от пагубного, по его мнению, их совмещения. Обоснованию данного предложения была посвящена значительная часть его теоретического труда «Организация адвокатуры» ${ }^{11}$ и статьи «Будущее русской адвокатуры» ${ }^{12}$. В основе взглядов Е. В. Васьковского лежало противопоставление правозаступничества как либеральной профессии или свободного искусства, предполагающего наличие специального образования, судебному представительству как ремеслу, не требующему такового. Преимущество правозаступника перед представителем, по мнению данного автора, заключается в том, что он стоит выше тяжущегося, он его патрон, т.е. покровитель и защитник, судебный же представитель находится к клиенту в отношении поверенного к доверителю, соответственно клиент для него - принципал, глава. Правозаступник должен быть независим от суда и прокуратуры и стоять рядом с ними в качестве равноправного им фактора правосудия. Наоборот, тяжущийся как частное лицо, как проситель, преследующий личные цели, всегда стоит и должен стоять ниже этих двух органов государственной власти. В таком же положении находится и поверенный, являющийся полным представителем тяжущегося. От правозаступника требуется, подобно тому, как от судьи и прокурора, бес-

10 См.: Гессен И. В. История русской адвокатуры. По изд. 1914 г. Т. 1. М., 1997. C. $44-45$.

11 Васьковский Е. В. Организация адвокатуры. Ч. 2. С. 142-162.

12 Он же. Будущее русской адвокатуры. По изд.1893 г. // Организация и деятельность адвокатуры в России / Авторы-составители В. М. Ануфриев, С. Н. Гаврилов. М., 2001. С. 141-153. 
корыстие при отправлении своих профессиональных обязанностей. Однако такое требование нельзя прилагать к поверенному, имеющему в виду только избавить тяжущегося от хлопот по производству дела и получить, таким образом, какую-либо денежную выгоду ${ }^{13}$. «Из всего сказанного понятно, - писал Е. В. Васьковский, - что совмещение правозаступничества с представительством в руках одного класса приводит к целому ряду неразрешимых противоречий. Оказывается, что такие лица должны обладать в одно и то же время самыми различными и в большинстве случаев прямо противоположными свойствами. Им приходится одновременно быть представителями свободной профессии и ремесленниками, являться на суде уполномоченными общества и вместе с тем наемными заместителями частного лица, быть патронами клентов и видеть в них принципалов, ни в чем не зависеть от них и находиться в полной зависимости, стоять наравне с судом и прокуратурой и в то же время ниже их, бескорыстно служить общественному благу и преследовать личную выгоду» ${ }^{14}$.

Однако столь резкое противопоставление правозаступничества и представительства, которое имеет место у данного ученого, едва ли обоснованно. Прежде всего обращает на себя внимание излишнее принижение им деятельности поверенных, низводящее его к простому ремеслу. Между тем подготовка судебных бумаг, представление доказательств и другие судебные действия требуют юридических знаний, и чем сложнее гражданский оборот и, соответственно, сложнее гражданские дела, рассматриваемые в суде, тем больший объем правовых знаний требуется при совершении этих действий. Кроме того, очевидно, что по гражданским делам правозаступник не является и не может быть полностью независимым от тяжущегося субъектом процесса, действующим исключительно по своему разумению. Собственно и сам Е. В. Васьковский, противореча себе, указывает перед этим на зависимость деятельности правозаступника от воли клиента, хотя и полагает, что такая зависимость определяется по началам публичного права ${ }^{15}$.

Что же касается бескорыстности правозаступника, на которую также ссылается автор, то им же приводятся ранее примеры из практики тех стран, в которых правозаступничество на тот момент было отделено от представительства, свидетельствующие о большой щепетильности правозаступников в вопросах получения денежных сумм от клиентов. «Хотя иск о гонораре воспрещен в Англии законом, а во Франции и Бельгии ${ }^{16}$ сословными правилами профессии, зато адвокаты этих стран имеют другие, косвенные спо-

13 Он же. Организация адвокатуры. Ч. 2. С. 142-145.

14 Васьковский Е. В. Организация адвокатуры. Ч. 2. С. 145.

15 Там же. С. 144.

16 Об особенностях разделения труда по судебному представительству и защите тяжущихся в Бельгии см.: Мальшщев К. Указ. соч. С.211. - В. И. 
собы, вполне заменяющие им прямое требование. Так, в Англии, по свидетельству Форсита, принадлежащего к сословию адвокатов, «гонорар всегда определяется поверенным и обозначается на оборотной стороне акта, посылаемого барристеру». Так как, по установившемуся обычаю, адвокат не входит в личные отношения с клиентами, а все дела ведутся при участии и посредстве поверенного, то понятно, что адвокат рискует не получить гонорара только в случае недобросовестности поверенного. «Но, конечно, - замечает Форсит, - он может отклонить принятие дела от поверенного, честность которого кажется ему подозрительной, если гонорар не будет уплачен немедленно».

Французские адвокаты прибегают к различным способам, чтобы обеспечить себя от недобросовестности клиентов. Прежде всего за уплатой гонорара адвокату обязан следить поверенный, ведущий дело вместе с ним. Он может вознаградить адвоката из собственных средств, а затем требовать возмещения расхода с клиента. Далее, на практике образовался обычай уплачивать часть гонорара до начала дела, в виде аванса. Наконец, если клиент покидает одного адвоката и обращается к другому, то правила профессии предписывают последнему не принимать дела, не удостоверившись сначала, что прежний адвокат удовлетворен вполне.

В Бельгии уплата гонорара авансом не дозволяется, но зато принято, чтобы клиент оставлял гонорар в виде залога у поверенного, который бы после окончания тяжбы передавал его адвокату. Другие два способа, употребляющиеся во Франции, приняты и в Бельгии.

Таким образом, и в Англии, и во Франции, и в Бельгии гонорар только в теории считается необязательным подарком, а на самом деле клиенты понуждаются к уплате его, хотя и не прямыми, а косвенными способами» ${ }^{17}$.

С течением времени меры предосторожности, направленные на обеспечение получения адвокатом гонорара, лишь усиливались. Так, по свидетельству молодого парижского адвоката Филиппара - делегата первого международного конгресса адвокатов, состоявшегося летом 1897 г. в Брюсселе, во Франции «во избежание злой шутки со стороны клиента» стали заставлять его «всегда без исключения» платить гонорар целиком вперед ${ }^{18}$.

Изложенное невольно наводит, по крайней мере, на две мысли. Вопервых, представление о бескорыстном служении на благо общества было направлено на поддержание внешнего облика адвокатуры как преемницы древнеримских судебных ораторов, первые из которых, принадлежа к классу патрициев, действительно безвозмездно осуществляли защиту в суде (поскольку не нуждались в деньгах, а стремились за счет ораторского искусства выдвинуться и занять затем видное место в системе государственной вла-

17 Васьковский Е. В. Организация адвокатуры. Ч. 2. С. 114-115.

18 См.: Винавер М. Очерки об адвокатуре. СПб., 1902. С. 115. 
сти) и от которых желали вести свою «родословную» адвокаты указанных западноевропейских стран. Во-вторых, существовавшая система лишь облегчала адвокатам сбор денег с клиентов, перекладывая это, как показывает практика, не очень легкое и приятное бремя на поверенных.

На двусмысленность положения с уплатой гонораров, существовавшего во Франции, где правозаступничество было отделено от представительства, указывал Лашапелль - Монтморо, которого цитирует Е. В. Васьковский. По этому поводу данный автор писал: «Прибегая к посредничеству авуэ и заставляя его действовать вместо себя, адвокат вредит своему достоинству больше, чем если бы он шел прямо к цели и действовал сам, “один под открытым небом”. Скрываясь за подставным лицом, он, напротив, дает повод подозревать своему должнику, что хочет получить больше, чем следует, а третьим лицам - всегда злорадной публике, - что требует то, что ему не должны». С другой стороны, «адвокат, который не предъявляет исков о гонораре и который, чтобы никогда не делать этого, требует определенного выкупа наугад с того, чьи самые важные интересы он должен защищать, лицемер и фанфарон бескорыстия» ${ }^{19}$.

Необходимо отметить и то, что по своему содержанию правозаступничество и представительство сближаются настолько, что их бывает нелегко различить. В принципе представительство может заключаться не просто в совершении отдельных действий юридико-технического характера, а, как и правозаступничество, в защите интересов доверителя в суде в качестве самостоятельного объекта. Ввиду этого возможно его использование не только для замены не участвующего по той или иной причине в разбирательстве дела тяжущегося, но и для оказания некомпетентной в правовых вопросах стороне юридической помощи. Что представительство может иметь такую цель, видно из цитируемых Е. В. Васьковским слов В. М. Гордона. Говоря об институте представительства, последний пишет: «Он дает возможность отправлять посредством представителей свою юридическую деятельность таким лицам, которые сами по себе не могут этого сделать вследствие каких-либо естественных, юридических и нравственных препятствий (болезнь, отдаленность места деятельности, отсутствие дееспособности, неумение защчщзать свое дело на cyде (выделено мною - В. И.) и проч.)» ${ }^{20}$. Очевидно, что сходство решаемых правозаступниками и представителями в процессе задач и обусловило то обстоятельство, на которое указывает Е. В. Васьковский, что французские и английские поверенные (avoues, solicitors) получили с течением времени право исполнять в определенных случаях обязанности адвокатов, а итальянские адвокаты - заниматься судебным представительством ${ }^{21}$.

19 Васьковский Е. В. Организация адвокатуры. Ч. 2. С. 137.

20 Васьковский Е. В. Организация адвокатуры. Ч.1. С. 3.

21 Там же. С. 7. 
В частности, поверенные во Франции иногда могли выполнять функции адвокатов. Так, в этой стране ежегодно апелляционными судами определялись те суды первой инстанции, в которых за недостатком адвокатов поверенные могли вести устную защиту в делах, которые им были поручены. Поверенным предоставлялось право участвовать в прениях в судах как первой, так и второй инстанции по делам, решаемым суммарным порядком, и по процессуальным вопросам (incidents). Кроме того, вследствие недостатка или отказа адвокатов суд мог в каждом отдельном случае допускать поверенного к защите. Наконец, поверенные, имеющие степень лиценциата прав, могли исполнить обязанности адвокатов в тех делах, которые они вели ${ }^{22}$. Таким образом, при наличии соответствующих обстоятельств поверенный во Франции мог выступить в качестве правозаступника по любому делу. Из изложенного видно, что и в данной стране на практике в целом ряде случаев допускалось совмещение выполнения обязанностей поверенного с выполнением обязанностей адвоката-правозаступника.

В Англии поверенные имели право выступать в качестве адвокатов, т.е. вести успешную защиту в низших судах (мировых, полицейских и т.п.), где барристеры обыкновенно не вели дел ${ }^{23}$.

Вызывает сомнение и не подтверждается практикой высказываемый тем же автором взгляд, согласно которому поверенный вовсе не должен обладать большей юридической подготовкой, чем сам тяжущийся ${ }^{24}$. Из излагаемого Е. В. Васьковским получается, что поверенный представляет из себя некий механизм, зеркально повторяющий те же действия, которые совершил бы тяжущийся, если бы только он лично участвовал в процессе. Однако на самом деле к помощи поверенного нередко прибегают и для того, чтобы использовать его правовые знания и опыт, а не только для совершения им таких действий, которые, в принципе, мог бы совершить и сам тяжущийся. «Чтобы получить исполнительный лист по закладной или описать с судебным приставом имущество должника, вовсе не нужно быть ученым юристом», - пишет Е. В. Васьковский ${ }^{25}$. «Мы уже говорили, - отмечает он в другом месте своей работы, - что обязанности поверенных сводятся к ведению бесспорных гражданских дел и к ходатайству по гражданским спорным и мелким уголовным процессам. Отсюда видно, что для них вполне достаточно обладать некоторыми чисто практическими сведениями по юриспруденции, именно: быть знакомыми с формами составления судебных бумаг, сроками, порядком исполнения решений и т.п. Для приобретения таких сведений не нужно ни оканчивать университет, ни подвергаться подготовке в ка-

22 Васьковский Е. В. Организация адвокатуры. Ч. 1. С. 174-175.

23 Там же. С. 221.

24 Васьковский Е. В. Организация адвокатуры. Ч. 2. С. 144.

25 Там же. С. 146. 
честве кандидатов на судебные должности. Следует только лиц, выставляющих свою кандидатуру на места поверенных, подвергать практическому экзамену, подобному тому, какой существует у нас для нотариусов» ${ }^{26}$. Но, как показывает современная российская практика, в некоторых случаях, например, того же производства описи имущества, о котором говорит указанный автор, для решения отдельных вопросов может потребоваться даже обращение в Конституционный Суд РФ. Трудно себе представить, чтобы в те времена, к которым относится написанное Е. В. Васьковским, у поверенных при совершении ими тех или иных действий не возникало подобных проблем.

Мнение, аналогичное в этой части мнению Е. В. Васьковского, высказывал А. М. Пальховский, который говорил следующее: «...Понятие, соединяемое нами с адвокатурой, как представительницей знания, науки, не может, да и не должно быть распространено на всех без исключения лиц, которые играют роль представителей сторон при совершении тех или других судебных действий, при ведении тех или других исков, при защите тех или иных обвиняемых. Вам нужно, например, навести какую-нибудь справку в суде, взять копию с решения, получить исполнительный лист, представить его судебному приставу, получить взысканные деньги, представить ко взысканию просроченную закладную, заемное письмо, вексель, представить к утверждению вполне правильно составленное духовное завещание, просить суд о вводе во владение, быть при вводе, или вам нужно продать дом, купить землю и совершить все установленные законом действия по укреплению и отчуждению недвижимых имуществ, или, наконец, вам необходимо явиться в суд, положим, по обвинению полициею в неочистке ретирадных мест вашего дома - неужели во всех этих случаях вы непременно должны обращаться к адвокату, как к представителю науки, знания? Неужели вы не можете уполномочить на совершение этих судебных действий всякое лицо, к которому имеете простое, обыкновенное доверие, основывая последнее ни на обширной эрудиции лица, ни на его высоких нравственных достоинствах? Все эти действия требуют почти исключительно только уменья подписать свою фамилию и наличного присутствия в суде; никаких объяснений, никаких рассуждений в данных случаях от поверенного не требуется, - он может пребывать в совершенном молчании, и дело совершится так же хорошо, как если бы вел его первейший правовед в мире. Таким образом, сама собою возникает существенная практическая потребность предоставить всякому, имеющему право вступать в договоры, т.е. лицу правоспособному и прав не лишенному, принимать на себя ходатайство по получению разных бумаг от судебных и административных мест, по предъявлению бесспорных исков, по делам охранительного судопроизводства, по приведению судебных решений в исполнение, а также по совершению всех действий в

26 Васьковский Е. В. Организация адвокатуры. Ч. 2. С. 198. 
нотариате. Нет никакого разумного, на серьезных соображениях построенного основания вводить все эти действия в сферу адвокатской деятельности, как исключительную ее принадлежность, адвокату тут делать нечего, место его может быть занято всяким. Если же мы теперь примем в соображение, что бесспорные иски, дела по охранительному судопроизводству, по приведению решений в исполнение, а также сношения с нотариатом и мелкие уголовные дела в пределах мировой юрисдикции составляют громадный процент дел в нашем юридическом обороте, то предоставление права заниматься ведением этих дел всякому чрезвычайно облегчит общество от совершенно ненужной для него в этих случаях адвокатской помощи и в то же время послужит весьма рациональным средством к возвышению адвокатуры на ту степень значения, какое она должна иметь, как орган юридической интеллигенции» ${ }^{27}$.

Однако утверждение автора, что при совершении перечисленных им действий «адвокату делать нечего», едва ли было верно для всех случаев. Очевидно, что даже при предъявлении обвинения в неочистке «ретирадных мест» дома, как показывает жизнь, могут возникать юридические проблемы, требующие вмешательства правоведов, не говоря уже о действиях типа представления к утверждению «вполне правильно составленного» духовного завещания. Разумеется, сказанное не означает, что во всех вышеуказанных действиях и во всех случаях требуется участие адвоката. Получить какую-либо справку в суде, копию решения суда и т.п. в большинстве случаев можно, не являясь адвокатом и юристом вообще. Между тем для совершения подобных действий не требуется учреждения целого сословия поверенных, поскольку вполне можно обойтись содействием помощников адвокатов, секретарей, родственников, супруга, знакомых тяжущегося, других лиц, а не замкнутого круга судебных представителей, который предлагал ввести Е. В. Васьковский ${ }^{28}$ и который соответствовал бы европейским «стандартам».

В связи со сказанным едва ли имеет смысл говорить о некоей непроходимой грани, существующей между правозаступничеством и представительством, о которой ведет речь, утверждая, что «сферы их деятельности не совпадают и, по существу своему, они не имеют ничего общего между собой» ${ }^{29}$, и к установлению которой фактически призывает Е. В. Васьковский. Коренное же, основное заблуждение данного ученого заключалось в том, что он полагал, что адвокат-правозаступник осуществляет публично-правовую функцию, а адвокат, выступающий в качестве представителя, - нет. «Отсюда ясно, - пишет он, - капитальное различие между внутренней природой правозаступничества и судебного представительства, а вследствие этого и меж-

\footnotetext{
27 Пальховский А М. О праве представительства на суде. М., 1876. С. 168-169.

28 См.: Васьковский Е. В. Организация адвокатуры. Ч. 2. С. 48-52.

29 Там же. С. 143.
} 
ду задачами их. В то же время, как первое необходимо не только для граждан, но и в интересах общества, государства и суда и, содействуя отправлению правосудия, является институтом публичного права, второе вызвано к жизни потребностями частных лиц, существует для их удобства и, имея в виду только служение частным интересам, носит исключительно частноправовой характер $\rangle^{30}$. Конечно, правозаступничество по ряду признаков отличается от представительства и их разграничение в дореволюционной юридической литературе имело определенный смысл, тем более что в ряде стран Западной Европы они различались, а в некоторых странах различаются и до сих пор, не только теоретически, но и на практике. Однако использование адвокатурой частноправового по своей природе института представительства также имеет публично-правовое значение, и для общества, по большому счету, безразлично, каким образом адвокаты выполняют задачу защиты интересов членов общества в сфере правосудия - посредством ли осуществления правозаступничества, т.е. выступая в качестве самостоятельных участников процесса, либо посредством осуществления представительства, т.е. выступая от имени тяжущихся, главное для общества - чтобы данная задача была реально выполнена. Здесь можно спорить лишь о том, какая форма защиты более эффективна в условиях конкретной страны, но не о том, выполняется ли при ведении адвокатами дел в суде в качестве представителей публично-правовая функция или нет. Иначе можно было бы прийти к странному выводу, что, например, выступая с речью в судебных прениях, адвокат выполняет такую функцию, а при представлении им доказательств в суд для обоснования позиции своего доверителя дело обстоит по-другому. С учетом изложенного нельзя согласиться с мнением Е. В. Васьковского, согласно которому представительство сторон и их интересов на суде, посредничество между тяжущимися и органами власти является ненужным ни для правосудия, ни для государства и, будучи только отступлением от общего правила судопроизводства, допускается исключительно для удобства частных лиц ${ }^{31}$. В одном месте своей работы автор приближается к пониманию более существенного значения представительства, чем просто выполнение неких технических действий, когда говорит: «Деятельность представителей - деятельность судебная; они посредники между тяжущимися и судом; они приходят в соприкосновение с органами правосудия, затрагивают не только интересы частных лиц, но и интересы правосудия, а следовательно, государства» ${ }^{32}$.

Вместе с тем такая оценка значения деятельности судебного представителя является в значительной мере формальной: раз представитель, участвуя в процессе, вступает в контакт с судом, значит затронутыми оказыва-

30 Васьковский Е. В. Организация адвокатуры. Ч. 2. С. 25.

31 Там же. С. 72.

32 Васьковский Е. В. Организация адвокатуры. Ч. 2. С. 49. 
ются интересы правосудия. Однако, если в качестве представителя выступает адвокат, то он тем самым выполняет и делегированную ему государством функцию защиты интересов частных лиц, носящую публично-правовой характер, а не просто занимается ремесленническим трудом, о низменном характере которого на протяжении всей своей работы, противопоставляя ему правозаступничество как более возвышенное занятие, пишет Е. В. Васьковский. В связи с этим нельзя согласиться с его утверждением, что «существование поверенных не нужно ни для общества, ни для государства, а вызвано исключительно интересами отдельных частных лиц» ${ }^{33}$.

«К чему же разделять, - продолжает свой анализ тот же автор, - функции теснейшим образом связанные между собой? Если дело сначала попадает в руки поверенного, который собирает фактический материал и доказательства, сочиняет судебные бумаги и вообще распоряжается делом как хозяин, то, не будучи специалистом, он может упустить из виду много важных обстоятельств; между тем адвокат, опираясь на собранный поверенным материал, не в состоянии поправить дела на суде. «Сколько раз, - говорит французский адвокат Одилон Барро, - мои товарищи и я, приглашенные защищать дело, сожалели о том, что не участвовали в предварительной письменной подготовке его» ${ }^{34}$.

Однако такого рода проблема, по мнению Е. В. Васьковского, на самом деле не касается сущности вопроса. Во-первых, она имеет значение только для тех дел, где правозаступники и поверенные действуют совместно, т.е. для гражданских спорных дел, и не относится ко всем прочим. Во-вторых, если предоставление поверенным предварительной подготовки действительно нецелесообразно, то это неудобство весьма легко устранить не полным уничтожением института поверенных, а изменением границ между деятельностью их и адвокатов. Что касается «единства ведения дела», то, как полагает Е. В. Васьковский, это пустая фраза. Ведение дела, конечно, требует одного определенного плана защиты или нападения, но самый процесс ведения распадается на несколько независимых стадий. Единство ведения необходимо в том смысле, чтобы от подачи прошения до постановления судом решения одно лицо руководило юридической стороной дела. Но отсюда вовсе не следует, чтобы это лицо само подавало все бумаги, уплачивало пошлины, просило о назначении или отсрочке дела, приводило решение в исполнение, описывало имущество должника и т.п. Такие действия в сущности не имеют ничего общего с внутренним единством процесса и могут быть предоставлены другому лицу ${ }^{35}$.

Сказанное Е. В. Васьковским не может не вызывать замечаний. Вопервых, непонятно, что же предлагает автор делать с гражданскими спор-

33 Там же. С. 139-140.

34 Васьковский Е. В. Организация адвокатуры. Ч. 2.С. 149-150.

35 Там же. С. 150-151. 
ными делами, составляющими весьма важную категорию дел. Не обращать внимания на ту практическую проблему, на которую указывал цитируемый Е. В. Васьковским Одилон Барро, из-за которой осуществляемая правозаступниками защита в суде не обеспечивала должную защиту интересов тяжущихся? Во-вторых, автор фактически проводит здесь свою собственную точку зрения, согласно которой в уголовном процессе судебное представительство, по общему правилу, вовсе недопустимо ${ }^{36}$, в то время как во Франции и Англии, опыт которых он берет за основу, поверенные являются маклерами, агентами и ходатаями по уголовным делам ${ }^{37}$. Очевидно, однако, что подобное положение сложилось в указанных странах не случайно и было направлено на освобождение адвокатов-правозаступников от рутинной и не требующей глубоких юридических познаний деятельности не только по гражданским, но и по уголовным делам. Почему же подобное освобождение в принципе («по общему правилу», выражаясь его словами) недопустимо, Е. В. Васьковский не объясняет. Почему, например, поверенный может навести какую-либо справку в суде по гражданскому делу, а по уголовному делу он этого делать не может, а делать это должен только правозаступник? Непонятна также причина, по которой тот же автор признает представительством лишь замену одним лицом другого в судебном заседании ${ }^{38}$, в том числе ведение тех маловажных уголовных дел, в которых не требуется личная явка обвиняемого ${ }^{39}$. В этом случае становится неясным, к какой же категории юридических действий относятся иные имеющие процессуальное значение действия, совершаемые поверенным за своего доверителя по отношению к суду вне судебного заседания. Не являющимися представительством?

Среди российских юристов на практическую нецелесообразность разделения в процессе функций правозаступника и поверенного указывал А. М. Пальховский. Данный автор по этому поводу писал: «Предоставить право принимать на себя ведение дел тяжущихся, входить с ними в объяснения, узнавать от них об основаниях тяжбы, подвергать юридическому анализу эти основания, собирать доказательства в пользу иска или ответа, наконец формулировать исковое требование или ответ на него и представить все это суду по принадлежности, - предоставить все это совершить лицу представителя (в смысле французского ovoue, английского sollcitor'a, attorney’я), а лицу защитника (в смысле французского avocat, или английского barrister'a, serjeant'a at law) предоставить право только давать советы тяжущимся и устно защищать их на суде - такое деление не может быть названо рациональным. Участие лица, завершающего процесс своею речью, необходимо и в самом начале процесса, - и это

\footnotetext{
36 Васьковский Е. В. Организация адвокатуры. Ч. 2. С. 24.

37 Там же. С. 153.

38 Там же. С. 24-25.

39 Там же. С. 162.
} 
одинаково как в гражданском, так и в уголовном деле. Судебные прения всегда основываются на предварительно собранном и заготовленном материале, которым, в огромном большинстве случаев, и обусловливается их успешность и неудача» ${ }^{40}$.

На естественный характер соединения правозаступника и представителя в одном лице указывалось и К. Малышевым: «...Надобно принять во внимание, что та и другая деятельность в процессе могут составить промысел или занятие одних и тех же лиц, что это соединение даже вполне естественно и вызывается в истории потребностями юридического быта и натуральным порядком вещей. В самом деле, если заступник или адвокат может оказывать юридическую поддержку тяжущейся стороне, если он обладает для того достаточными техническими сведениями и опытностью в судебных делах, если сторона имеет право выбрать себе поверенного или представителя по своему усмотрению и в интересах лучшей защиты своего дела, то очевидно, что ей нет надобности выставлять в свою защиту непременно двух лиц - поверенного, не сведущего в праве, и особого адвоката для его поддержки; напротив, в интересах тяжущегося - соединить эти роли в одном лице, избрав поверенного из людей, сведущих в законах» ${ }^{41}$. Вместе с тем автор правильно отмечает связь отграничения функций правозаступника от функций поверенного в тех странах, где оно существовало, с разделением труда ${ }^{42}$, в силу наличия которой, очевидно, ему следовало бы обратить внимание на то, что при определенных условиях такое отграничение может быть целесообразным.

Применительно к России, Е. В. Васьковский предлагает изменить, по сравнению с Францией и Англией, круг деятельности поверенных по отношению к кругу деятельности правозаступников, указывая на то, что в обеих этих странах на поверенных возложена вся письменная подготовка процессов, т.е. сочинение состязательных бумаг, как в спорных, так и в бесспорных, как в гражданских, так и уголовных делах. «Такого порядка вещей, - замечает он, - нельзя признать желательным: сочинение состязательных бумаг вещь настолько важная для процесса и столь тесно связанная с ходом его, что отделять ее от устной защиты и предоставлять поверенным значит разрушать необходимое в интересах тяжущихся единство ведения дела...Судебная бумага (прошение, возражение, апелляция, кассация, частная жалоба и т.п.) служит, при господстве устности в процессе, тезисом, который развивается в заседании суда, или, еще лучше, программой, которую сторона выполняет своей речью. Отдавать выбор тезиса и составление программы одному лицу, вдобавок мало компетентному в этом, а развитие тезиса и вы-

\footnotetext{
40 Пальховский А. М. Указ. соч. С. 166-167.

41 Мальиев К. Указ. соч. С. 206.

42 Там же. С. 206-207.
} 
полнение программы возлагать на другое лицо - значит ставить в неудобное положение адвоката и подвергать опасности интересы тяжущегося. Юридической стороной спорного гражданского дела от подачи прошения до постановления решения должен руководить адвокат; поверенному же может быть предоставлено только собирание фактического материала, хождение по делу и исполнение решения» ${ }^{43}$.

С изложенными соображениями Е. В. Васьковского относительно нежелательности отделения составления судебных бумаг от устного выступления адвоката в суде сложно не согласиться. Однако принятие его предложения об изменении разграничения сферы деятельности правозаступников и поверенных означало бы не что иное, как начало разрушения устоявшейся системы разделения правозаступничества и представительства. Действительно, составление названных выше видов процессуальных документов требует, как правило, личной встречи и беседы лица, составляющего такой документ, с тяжущимся для выяснения обстоятельств дела, круга доказательств, на которые должна содержаться ссылка в этих документах и которые должны к нему прилагаться, позиции тяжущегося, результата, который для него желателен. В то же время именно освобождение правозаступника от подобных встреч и бесед, от подготовки многочисленных письменных обращений в судебные органы и составляет одну из основных целей разграничения деятельности правозаступников и представителей, без чего данное разграничение в значительной мере утрачивает свой смысл. Не случайным в связи с этим представляется то, что до недавнего времени, согласно правилам профессии, английский адвокат-барристер, лично встретившийся с клиентом неюристом, подлежал исключению из сословия. Нетрудно также заметить, что составление судебных бумаг правозаступником «плавно» переходило бы в сбор им доказательств, хотя бы и через поверенного, поскольку, как показывает практика, во многих случаях составление таких документов невозможно лишь со слов клиента, без предварительного ознакомления с имеющимися доказательствами. В свою очередь, это означало бы еще большее «размывание» различия между правозаступником и поверенным, снижение его практического значения.

Что же касается таких действий, как непосредственная подача всех бумаг в суд, уплата пошлин, доставка в суд ходатайства о назначении или отсрочке дела и других действий «технического» характера, то для освобождения действительно загруженного делами присяжного поверенного от их совершения не требовалось, как уже указывалось выше, создания отдельного сословия поверенных, а достаточно было использования его помощников, рассыльных и других служащих. Собственно говоря, так и делалось на практике.

43 Васьковский Е. В. Организация адвокатуры. Ч. 2. С. 198-199. 
Основная же, глубинная причина, по которой в России в результате судебных реформ не было и не могло быть введено деление на правозаступников и поверенных, состояла в значительно более низком уровне экономического развития России по сравнению с Францией и Англией, в которых такое деление существовало и которые, наряду с США, занимали в то время лидирующие позиции в мировой экономике. Эти страны превосходили и критикуемую Е. В. Васьковским на протяжении всей его работы за отсутствие в ней указанного деления Германию.

Доказывая, что если принять его предложение о введении для поверенных обязательной таксы, а для правозаступников предусмотреть получение вознаграждения в том размере, в каком найдет возможным предложить клиент, то клиенты будут находиться не только не в худшем, но даже в гораздо лучшем положении, данный автор сравнивает Францию и Германию. При этом он утверждает, что, как показывает опыт, во Франции издержки тяжущихся на адвокатов и поверенных в общем меньше, чем в Германии, где адвокаты-поверенные получают по соглашению солидные суммы ${ }^{44}$. Однако в другом месте своей работы Е. В. Васьковский приводит совсем другие данные о заработках адвокатов Германии. «Нигде, - писал еще в 1820 г. немецкий адвокат Ганс, - не вознаграждается адвокат хуже, чем в Германии, и нигде не получает он своего вознаграждения менее достойным образом. Мы удивляемся, слыша о громадных суммах, которые зарабатывают адвокаты Франции и Англии, и это можно объяснить только тем уважением, которым они пользуются, и прекрасным обычаем, по которому они принимают только добровольный гонорар от клиентов, вознаграждающих, в свою очередь, с большой охотой человека, который публично защищает их дело своим красноречием и знанием. Если мы слышим иной раз, что какой-нибудь немецкий адвокат приобрел себе своей практикой маленькое состояние, то он обязан им, наверное, не своим трудам в качестве адвоката, но таким занятиям, которые вовсе не относятся к адвокатской профессии, как-то: кураторством, управлением имуществами, опеками, торговлей и т.д., а чаще всего богатство и состоятельность отельных немецких адвокатов происходит от приданого их жен и наследств. Настоящая же юридическая практика ведет в нашем отечестве не к богатству, а едва к обыкновенному достатку». Слова Ганса, как удостоверяет Пришль, сохранили свою силу и по настоящее время относительно Германии и Австрии, и за немногими изъятиями в пользу отдельных лиц могут быть применены и к русским присяжным поверенным. Совсем в ином положении находятся адвокаты Англии, Франции и Бельгии. Еще в Средние века, когда германских адвокатов приравнивали к ремесленникам и ставили наряду с банщиками и резчиками свиней, Реньо д’Аси зарабатывал ежегодно по 200 тысяч фр., а Дю-Брюйель оставил после

44 Васьковский Е. В. Организация адвокатуры. Ч. 2. С. 151-152. 
себя состояние в 15-20 млн фр. В новое время дело нисколько не изменилось. Известно, что Жербье за один процесс получил 300 тыс. фр., Дюводье за другой процесс - пожизненную ренту в 40 тыс. фр. в год, а после смерти Дюпэна-старшего осталось имущества на 5 млн фр. Ни один австрийский или германский адвокат, несмотря на все свободные соглашения, таксы, судебные принуждения и понудительные исполнения, не заработал, быть может, даже в течение всей своей жизни такой суммы, какую Жербье, Дюводье и многие другие получали за один процесс в качестве добровольно подносимого подарка со стороны признательного клиента» ${ }^{45}$.

Нетрудно заметить, что изложенное в данном месте работы плохо согласуется с последующими утверждениями Е. В. Васьковского о том, что в Германии «адвокаты-поверенные получают по соглашению солидные суммы» и что «во Франции издержки тяжущихся на адвокатов и поверенных в общем меньше, чем в Германии». Можно понять также высказывавшуюся немецкими адвокатами обиду на худшее по сравнению с их французскими и английскими коллегами материальное положение, но было бы весьма наивно полагать, что если бы в Германии гонорары адвокатам стали выплачиваться по принципу «кто сколько даст», то деньги потекли бы к ним рекой. Скорее всего, наблюдалась бы обратная картина, и дело тут не в «совестливости» французских и английских клиентов и «отсутствии совести» у клиентов немецких. Очевидно, что коренная разница заключалась в материальных возможностях тех и других. Германия, долгое время раздробленная на множество мелких государств (их количество, как известно, доходило до $300)$, в отличие от Франции и Англии, была не лучшим местом для экономического процветания. Приводимые же автором суммы гонораров говорят лишь о том, что во Франции было больше богатых людей, чем в Германии. Попытки же Германии в дальнейшем сравняться с Францией и Англией по уровню жизни населения стоили человечеству двух мировых войн.

К сказанному следует добавить, что если более высокие заработки французских и английских адвокатов были обусловлены добровольностью выплаты их клиентами гонораров и определением ими самими размера последних, то становится непонятным, зачем же нужно было в этих странах так тщательно разрабатывать и применять достаточно сложную систему обеспечения получения адвокатами гонораров от клиентов, о которой писал выше Е. В. Васьковский.

Обращает на себя внимание и то, что, говоря о большей, по его мнению, выгоде для клиентов деления на правозаступников и поверенных, автор не учитывает положения самих адвокатов. Могло ли быть выгодным и приемлемым для большинства адвокатов существование наряду с ними сословия поверенных, с которыми они должны были бы делить доходы, если мно-

45 Васьковский Е. В. Организация адвокатуры. Ч. 2. С. 123-124. 
гим присяжным поверенным приходилось ожидать первого своего гражданского дела по году и больше, несмотря на то, что они обладали и опытом и знаниями ${ }^{46}$ ? Как отмечал П. В. Макалинский, «заработок присяжных поверенных не только не представляется чрезмерно большим, но даже не вполне обеспечивает средства существования значительного большинства присяжных поверенных» ${ }^{47}$. Не случайно в связи с этим позиция Е. В. Васьковского, его попытка «осветить факелом науки темную бездну, пересекающую тот путь, по которому идет русская адвокатура» ${ }^{48}$, не были поддержаны присяжными поверенными, хотя, на первый взгляд они были направлены на защиту их интересов. В комиссии же по пересмотру судебных уставов лишь трое ее членов (В. Д. Спасович, А. Л. Боровиковский и Е. В. Васьковский) указывали на необходимость разделить профессии правозаступничества и судебного представительства или по меньшей мере избавить присяжных поверенных от участия в исполнении судебных решений, большинство же членов комиссии с этим не согласилось ${ }^{49}$.

Возможные последствия принятия его предложения фактически описаны самим автором. «...Отделение правозаступничества от судебного представительства, - пишет Е. В. Васьковский, - является почти неосуществимым в тех странах, где, как, например, в Германии, Австрии и Италии, сословие адвокатов до того переполнено, что члены его, несмотря на предоставленную им монополию и даже обязательное участие в процессе, не в состоянии жить с одной практики, а принуждены предаваться всяким побочным занятиям. Запретить такие занятия и сузить сферу деятельности значило бы разорить и пустить по миру сотни адвокатов и их семейств». «К счастью, - продолжает автор, - Россия находится в несравненно лучших условиях. Адвокатура у нас не только не переполнена, но даже по численности не соответствует потребности населения в юридической защите. Помимо того, чтобы вознаградить адвокатов за отнятие у них функций судебного представительства и побочных занятий, следует предоставить им, как это сделано всюду на западе Европы, монополию ведения гражданских и уголовных дел в общих судебных учреждениях и признать обязательным участие адвокатуры в уголовном процессе, по меньшей мере в делах, разбираемых с участием присяжных заседателей ${ }^{50}$.

Между тем присяжная адвокатура в России действительно не была переполнена потому, что занятие адвокатской деятельностью (и об этом долж-

46 Пальховский А. М. Указ. соч. С. 23.

47 Макалинский П. В. С.-Петербургская присяжная адвокатура. Деятельность С.-Петербургского совета и общих собраний присяжных поверенных за 22 года (1866-1888 гг.). СПб., 1889. С. 191.

48 Васьковский Е. В. Будущее русской адвокатуры. С. 152-153.

49 Васьковский Е. В. Курс гражданского процесса. Т. 1. М., 1913. С. 343.

50 Васьковский Е. В. Организация адвокатуры. Ч. 2. С. 210-211. 
но было быть хорошо известно самому автору, который во время написания своего труда был помощником присяжного поверенного) не гарантировало многим достаточных средств к существованию. В свою очередь, это было связано не с небольшим количеством дел, рассматриваемых в судах, по которым требовалось оказание сторонам юридической помощи (таких дел в России всегда хватало), а низкой платежеспособностью подавляющего большинства населения, не способного на должном уровне оплачивать правовую помощь. При таких условиях весьма немногие известные присяжные поверенные имели высокие доходы, материальное же положение остальных адвокатов было значительно хуже. В этом отношении Россия не находилась «в несравненно лучших условиях», чем Германия, Австрия и Италия. Что же касается предлагаемого Е. В. Васьковским в порядке компенсации за те материальные потери, которые они должны будут понести в случае запрещения осуществления ими судебного представительства, установления для присяжных поверенных монополии ведения ими дел в суде, то в российском обществе и в правительственных кругах существовало (и сохраняется до сих пор) крайне отрицательное отношение к этой идее.

Имелся (и сохраняется в наше время) еще один довод против разделения двух указанных профессий. По поводу его Е. В. Васьковский писал: «Опыт показывает, по словам некоторых авторов, что в тех странах, где правозаступничество отделено от представительства, адвокаты легко попадают в тягостную материальную зависимость от поверенных. Дело в том, что тяжущиеся обращаются раньше к поверенным, которые уже по своему усмотрению делают выбор адвоката и приглашают по большей части такого, с которым состоят в каких-либо особых отношениях» ${ }^{51}$. Однако, «этот довод, имеющий, действительно, фактическое основание», по словам автора, «далеко не так важен, как кажется, на первый взгляд. Если во Франции и Англии адвокаты попадают в зависимость от поверенных, то это происходит оттого, что в обеих странах участие поверенных обязательно в гражданском процессе и что, кроме того, они являются маклерами, агентами и ходатаями по уголовным делам. Будь им предоставлено одно судебное представительство, ничего подобного не могло бы произойти. Адвокаты действовали бы совершенно самостоятельно в уголовном процессе, и некоторая зависимость от поверенных в гражданских спорных делах не имела бы большого значения, в особенности если бы закон не требовал обязательного участия поверенных в процессе» ${ }^{52}$. По поводу приведенных возражений следует заметить, что, поскольку защита по уголовным делам в большинстве случаев осуществлялась раньше (и осуществляется сейчас) по назначению и за минимальное вознаграждение, «некоторая зависимость правозаступников от поверенных

51 Васьковский Е. В. Организация адвокатуры. Ч. 2. С. 152-153.

52 Там же. С. 153. 
в гражданских спорных делах» на самом деле была бы весьма чувствительной для адвокатов в материальном плане. Говоря же о том, что такая зависимость снижается, если закон, в отличие от Франции и Англии, не требует обязательного участия поверенных в процессе, автор как бы намекает на то, что адвокату-правозаступнику в связи с этим было бы вовсе не обязательно обращаться к поверенному, чтобы через него вступить в отношения с потенциальным клиентом. Однако именно отсутствие непосредственного контакта с доверителем и всех связанных с согласованием условий о размере и порядке выплаты гонорара, избранием методов и способов защиты и т.д. нравственных издержек и является характерным признаком правозаступника, отличающим его от поверенного и поднимающим его, по мнению сторонников раздельного существования правозаступничества и представительства, на недосягаемую высоту по сравнению с последним. Если же понимать приведенный Е. В. Васьковским контраргумент не таким образом, то он вообще утрачивает всякий смысл. К сказанному остается добавить, что лишение поверенных заработков, связанных с выполнением ими их функций по уголовным делам, подобных тем, которые они имели во Франции и Англии, нанесло бы весьма ощутимый удар по всему этому сословию и сказалось бы отрицательно на его формировании и деятельности.

Разделение на адвокатов и поверенных в ряде случаев также отрицательно влияло на уровень профессионализма и добросовестности адвокатов. Так, известный французский судья Ларош-Флавэн писал: «Есть адвокаты, которые не изучают ни людей, ни права, ни постановлений. Причиною этому некоторые стряпчие, дающие вести дела только родственникам и приятелям. Эти последние, уверенные, что недостатка в делах у них не будет, как бы они их ни вели, никогда не заглядывают в книги». И дальше он замечает, что невежественные адвокаты обращаются в кляузников ${ }^{53}$.

Отстаивая свою точку зрения, согласно которой отделение правозаступничества от представительства в России является весьма целесообразным, Е. В. Васьковский пишет: «Французские и итальянские писатели, отрицающие важность разделения, имеют в виду только порядки своего отечества, при которых адвокаты попадают в зависимость от поверенных и испытывают неудобства от того, что предварительная подготовка дел принадлежит не им» ${ }^{54}$. В то же время те «порядки», которые он предлагает ввести в России с целью устранения данных проблем, противоречат, как отмечалось выше, не только опыту указанных стран, но и самой сути предлагаемого им отделения. Представляется, что, обосновывая свою позицию, ав-

53 Молло М. Правила адвокатской профессии во Франции. По изд. 1894 г. // Традиции адвокатской этики. Избранные труды российских и французских адвокатов (XIX - начало XX в.) / Сост.: И. В. Елисеев, Р. Ю. Панкратов. СПб., 2004. С. 268.

54 Васьковский Е. В. Организация адвокатуры. Ч. 2. С. 156. 
тор действует «по заранее заданной теоретической схеме», не обращая внимания на явные противоречия в своей аргументации, несоответствие его рекомендаций сути разделения правозаступничества и представительства вообще, а также социально-экономическим условиям России, отличавшим ее ранее (и отличающим теперь) от Франции, Англии и Бельгии. В связи с изложенным нельзя согласиться и с конечным выводом автора, согласно которому в России «в интересах правосудия, а равным образом, и для процветания адвокатуры необходимо отделить правозаступничество от судебного представительства» ${ }^{55}$.

Позднее Е. В. Васьковский более объективно подходил к решению данного вопроса, хотя и не отказался от своей прежней точки зрения. По поводу организации адвокатуры в Германии, Австрии и большинстве других цивилизованных государств он писал: «Она основана на совмещении обязанностей правозаступничества и судебного представительства в руках одного класса лиц. Основная причина слияния этих двух функций, столь различных по своему существу, заключается в том, что обе они тесно соприкасаются по сфере своей деятельности. Вследствие этого соединение обеих представляет для тяжущихся несомненное удобство: каждому тяжущемуся приходится пользоваться услугами не двух лиц, а только одного, которое довольствуется меньшим вознаграждением и в то же время несет полную и нераздельную ответственность за добросовестное ведение дел. Равным образом, выгодно соединение обеих функций как адвокатам, избавляющимся от неприятной зависимости со стороны поверенных, так и поверенным, которые получают возможность вести дела самостоятельно, без участия адвокатов. Этим обусловливается постоянно проявляющаяся в истории адвокатуры тенденция к слиянию правозаступничества с судебным представительством. Уже в императорском Риме адвокаты стали исполнять обязанности поверенных. Такое же соединение обеих функций произошло в Германии и происходит в настоящее время в Италии и Голландии» ${ }^{56}$. Как указывает автор, в Соединённых Штатах Америки обе профессии тоже слиты в одну ${ }^{57}$.

Нетрудно заметить также, что у Е. В. Васьковского речь фактически шла не о разграничении функций правозаступничества и представительства, а о введении двухстепенной адвокатуры, причем в виде, неизвестном западноевропейским странам, на опыт которых ссылается автор. Как верно подметил М. Винавер, «наши приверженцы расчленения адвокатуры стараются избегнуть несомненных недостатков этой системы, предоставляя присяжным поверенным и руководство процессом, и составление состязательных бумаг, и непосредственные сношения с клиентом, - и отводя адвока-

55 Васьковский Е. В. Организация адвокатуры. Ч.2. С. 162.

56 Васьковский Е. В. Курс гражданского процесса. Т.1. С. 311-312.

57 Васьковский Е. В. Курс гражданского процесса. Т.1. С. 312 (сноска 3-ья). 
там второй степени особые категории дел: бесспорные дела, охранительные, конкурсные, дела мировой юстиции, дела по исполнению решений и т.п.» ${ }^{58}$.

Обосновывая целесообразность разделения функций правозаступника и судебного представителя, Е. В. Васьковский значительное внимание уделял нравственной стороне дела. По этому поводу он писал: «Как только к правозаступничеству присоединяется судебное представительство, по своей сущности коренным образом отличающееся от него, призванное служить иным потребностям, требующее от занимающихся им лиц других качеств (практической деловитости, ловкости, изворотливости), тотчас адвокатура приобретает двойственный характер, душа адвоката раздваивается...Из ученого эксперта по вопросам права, каким он был в качестве чистого правозащитника, адвокат становится практическим дельцом, маклером по юридической части, имеющим тем больше успеха в публике, чем больше сметливости, юркости и даже неразборчивости в средствах он проявляет при устройстве материальных интересов своих клиентов. Само собою понятно, что он не может уже претендовать на то высокое доверие и уважение суда и общества, каким был окружен раньше, потому что «из-под его адвокатской тоги выглядывает портфель ходатая по делам», имеющего право, вдобавок, требовать от клиента вознаграждение за каждую написанную строчку, за каждый процессуальный шаг» ${ }^{59}$.

Изложенное выше, конечно, не означает огульного отрицания целесообразности разделения правозаступничества и представительства во всех странах мира, независимо от их конкретных условий. Его существование во Франции и Англии было обусловлено рядом причин. Первой из них была рецепция римского права, которая выразилась, в частности, в заимствовании уже в Средние века в некоторых странах той системы разграничения юридической помощи тяжущимся, которая была присуща римскому праву в классический период. Такую систему, однако, не следует считать простым повторением римской, поскольку в ней тяжесть знания права переместилась с поверенного на судебного оратора. Второй причиной явилось достаточное количество в этих странах оплачиваемых дел, что обеспечивало в целом благополучное в материальном смысле существование как правозаступникам, так и поверенным. В-третьих, «приискание» клиентов своего рода агентами адвокатов, каковыми являлись поверенные (стряпчие), специализировавшиеся на таком поиске, расширяли круг лиц, которым оказывали юри-

58 Винавер М. Указ. соч. С. 161.

59 Васьковский Е. В. Курс гражданского процесса. Т. 1. С. 318-319. На отрицательные последствия совмещения присяжными поверенными функций правозаступничества и судебного представительства ссылались также некоторые другие российские юристы (Обнинский, Вильский, Гребенщиков), которых цитирует в другой своей работе тот же автор (см.: Васьковский E. В. Организация адвокатуры. Ч. 1. С. 336-338). 
дическую помощь адвокаты. В-четвертых, адвокаты освобождались от рутинной, носившей в значительной мере технический характер работы, что позволяло им сосредоточиться на разработке юридической стороны дела и подготовке к выступлениям в суде, хотя здесь и возникали проблемы, связанные с неучастием адвоката в подготовке процессуальных бумаг и сборе доказательств.

Вместе с тем отзывы Е. В. Васьковского об адвокатуре тех стран, в которых сохранялось деление на адвокатов и поверенных, представляются чрезмерно восторженными. Об этом свидетельствует, в частности, анализ состояния французской адвокатуры, данный М. Винавером, который, являясь участником первого международного конгресса адвокатов, проходившего в 1897 г. в Брюсселе, имел возможность ближе познакомиться с данными об адвокатуре этой страны. М. Винавер отмечает многочисленные недостатки, присущие французской адвокатуре того времени: отсутствие внимания к сословию поверенных; чисто формальное отношение к занятиям со стажерами; фарисейские рассуждения французских адвокатов о бескорыстном оказании юридической помощи; отсутствие внутри страны каких-либо обществ и ассоциаций адвокатов; весьма слабое участие французской адвокатуры в оказании юридической помощи бедным; отсутствие интереса адвокатов к участию в политической жизни; ложный характер представления, будто во Франции много общественных деятелей и администраторов произошло из адвокатов; стремление во что бы то ни стало сохранить в неприкосновенности заветы старины; нежелание парижских адвокатов сотрудничать с адвокатами других стран; позерство и ложный пафос выступлений французских адвокатов ${ }^{60}$. «Из 1900 парижских адвокатов, - отмечает М. Винавер, - явились на конгресс, несмотря на близость расстояния, всего человек 5 ; на вопросный лист комитета был прислан из Парижа один ответ. Из числа явившихся на конгресс двое - как нам приходилось слышать - не смели выступить публично со своими замечаниями, особенно когда вопрос касался организации парижской адвокатуры: мужество их, говорят, слишком тяжело отозвалось бы на их карьере; поэтому один совершенно молчал, а другой говорил о порядках, существующих в Северной Америке» ${ }^{61}$. «Движение замерло, - говорит по поводу современного ему состояния французской адвокатуры М. Винавер, - и не ожило до наших дней. Культ старых традиций приобрел самодовлеющее значение, - круг жизни как будто совершен, и некуда дальше идти. Идеалы охраняются, но охраняются в вековой их нерушимости, - не по разуму, а по букве. В душной, непроветриваемой атмосфере явственно выступают симптомы разложения, и спасения против него ищут в строгом исполнении внешнего чина» ${ }^{62}$.

\footnotetext{
60 См.: Винавер М. Указ. соч. С. 108-121.

61 Там же. С. 120.

62 Винавер М. Указ. соч. С. 106.
} 
Н. П. Карабчевским была написана статья по поводу книги известного французского адвоката Леона Клери, в которой показаны отрицательные стороны деления французских адвокатов на avoués и avocats ${ }^{63}$. Как указывалось в данной книге, вместо солидарной, дружной работы и общности взаимных интересов avoués и avocats представляли собой два глухо враждующих лагеря завистников и конкурентов. При этом об avoués Клери писал как о вполне своеобразной касте дельцов, преданных исключительно своекорыстным материальным интересам, чуждых духу прогресса, видящих лишь в судебно-производственной рутине свой надежный оплот и все свое основание существования. В тиши своих кабинетов они стряпают кляузные бумаги, причем avoués почти не несут даже нравственной ответственности за исход процесса, поскольку непосредственно в процессе участвует avocat, неискусству которого им легко приписать всякий неуспех, всякий проигрыш. Однако окончание дел миром, широкая область юрисконсульства, наконец первоначальная постановка и направление процесса всецело находятся в руках avoués, нередко мало соответствующих и в умственном и в нравственном отношении стоящим перед ними задачам. Как отмечал данный автор, в обход закона и обычая действительность нагромождает во взаимных отношениях клиента к адвокату столько условного, лживого и ненормального, что лишь одни avoués самодовольно еще потирают себе руки, адвокаты же и клиенты одинаково кряхтят ${ }^{64}$.

В книге Клери ярко показана зависимость французского адвоката от авуэ. Не клиент, не общество кормит адвоката; его кормят и, разумеется, по возможности впроголодь, avoués и hommes d'affaires (деловые люди) ${ }^{65}$.

По замечанию Н. П. Карабчевского, такая характеристика взаимных отношений адвокатов и avoués подтверждается и его личными наблюдениями над профессиональным положением современных парижских адвокатов и их собственными воззрениями на этот предмет, хотя, по выражению автора, и «исключительно интимными» ${ }^{66}$.

По этому поводу Н. П. Карабчевский указывал на то, что еще со времен Мольера во французской литературе не прекращаются нападки, которые от времени до времени обостряются, посылаемые именно по адресу этой сложной, условной и мало доступной для публики организации взаимных отношений клиента и адвоката. Большинство же адвокатов, не дожидаясь реформы, стали сами разыскивать себе клиентов, открывать свои кабинеты для

63 Карабчевский Н.П. Современная французская адвокатура и новая школа судебного красноречия (по поводу книги Léon Cléry «Souwenirs du Palais») // Около правосудия: статьи, сообщения и судебные очерки. СПб., 1902. С. 1-42.

64 См.: Карабчевский Н. П. Указ. соч. С. 5-7.

65 Карабчевский Н. П. Указ. соч. С. 7-11.

66 Там же. С.7. 
консультации и принимать на себя, хотя и не официально, ведение дел в полном объеме ${ }^{67}$.

Отсутствует у Е. В. Васьковского объективный анализ и действительного состояния адвокатуры Англии, о которой он очень высоко отзывается, приводя при этом слова английского лорда, в своем учебном курсе ${ }^{68}$.

Обращаясь уже к нашему времени, следует отметить, что развитие адвокатуры в мире вполне определенно обнаружило тенденцию к объединению профессий лиц, оказывающих помощь тяжущимся в суде. Так, до 1971 года адвокатское сословие во Франции подразделялось на три замкнутые профессиональные группы: собственно адвокатов (les avocats), поверенных (les avoues) и стряпчих при коммерческих судах (les agrees). Закон 1971 года о реформе некоторых судебных и юридических профессий отменил это деление и ввел новую единую профессию адвоката (la nouvelle profession d'avocat), объединившую все три прежние упомянутые профессии.

С 1 января 1992 года во Франции создана новая профессия, члены которой стали носить звание адвоката: юрисконсульты (conseil juridique) получили право становиться членами орденов адвокатов. Теперь юрисконсульты вправе заниматься адвокатской деятельностью, а адвокаты могут исполнять функции юрисконсульта.

В отличие от французской адвокатуры, английская адвокатура на протяжении всего XX века развивалась в духе консервативного традиционализма. Однако и здесь постепенно стала все сильнее заявлять о себе тенденция к сближению профессий лиц, выполняющих адвокатские функции. Согласно ст. 27 Закона о суде и юридических услугах 1990 г. (Courts and Legal Services Act), право выступать перед судом (right of audience) в отношении любых процессов признается как за барристерами, уполномоченными Советом барристеров Англии и Уэльса (The General Council of the Bar of England and Wales), так и за солиситорами, уполномоченными Юридическим обществом (The Law Society of England and Wales). Соответственно, солиситоры получили право вести дела своих клиентов в судах всех инстанций, а не только в низших судах - судах графств и магистратских судах, как это имело место ранее. Вместе с тем, если получение в установленном порядке звания барристера автоматически дает право на выступление во всех судах, то вопрос о предоставлении права солиситору на осуществление представительства стороны в судах высших инстанций решается в каждом отдельном случае Юридическим обществом. В соответствии со сложившейся практикой предпочтение при этом отдается лицам, имеющим стаж работы солиситором не менее 15 лет, причем солиситоры, уполномоченные Юридическим обществом на ведение дел в высших судах, должны быть зарегистрированы в качестве «солиситоров-адвокатов».

67 Там же. С. 12.

68 Васьковский Е. В. Курс гражданского процесса. Т. 1. С. 321. 
В результате произошедщих изменений адвокатура, естественно, почувствовала некоторую конкуренцию со стороны совершенно дружественной ранее, по словам самих барристеров, профессии. Очевидно, также, что было положено начало процессу стирания четкой грани и размежевания между традиционными полномочиями и сферой деятельности солиситоров и барристеров, причем наблюдается не только сближение профессии солиситора с профессией барристера, о котором шла речь выше, но и движение в противоположном направлении, т.е. сближение правового положения барристера с правовым положением солиситора.

В этой связи следует упомянуть реформы Вульфа конца 90-х гг. прошлого века, коснувшиеся фундаментальных принципов гражданского процесса в Англии и, в частности, сместившие акценты в способах разрешения споров в сторону внесудебного, мирового урегулирования, что также косвенным образом сделало жизнь рядового (и особенно начинающего) адвоката более тревожной ${ }^{69}$. В результате адвокатам пришлось внести изменения в свои профессиональные правила, которые позволили им получить в различных случаях возможность работать напрямую с клиентами - заказчиками (физическими и юридическими лицами, не солиситорами ${ }^{70}$ ). Сначала речь шла только о предоставлении напрямую услуг представителям тех профессий (т.е. их фирмам), деятельность которых также регулируется строгими профессиональными правилами, - архитекторам, бухгалтерам, финансистам, страховщикам и т.п. Потом стало возможным работать напрямую с любыми физическими и юридическими лицами, но при соблюдении определенных условий, а именно: три года стажа по специальности после получения квалификации барристера, окончание краткого (однодневного) курса по работе с клиентами - неюристами) и, наконец, регистрация в качестве адвоката, ведущего дела напрямую, в регулирующем органе.

Вместе с тем непосредственная работа с клиентами не предполагала возможности полного и абсолютного дублирования деятельности солиситоров. Оставались некоторые (хотя и совсем немногочисленные) аспекты ведения дел, которые все еще были «подведомственны» солиситорам. Например, барристеры не могли совершать такие процессуальные действия, как подача документов в суд. При этом составлять документы не воспрещалось (даже наоборот: традиционно многие судебные формы и прочие важные документы заполняются и составляются именно барристерами); вот только физически отправить или отнести их в суд барристеры не могли - это не разрешалось правилами. Также барристеры не имели права самостоятельно, без участия соли-

69 См.: Шостранд Е. Радикальные реформы в английской адвокатуре // Новая адвокатская газета. 2010. № $23 / /<\mathrm{http}$ ://www.advgazeta.ru/rubrics/11/582> (последнее посещение - 7 февраля 2012 г.).

70 Англ. lay clients (непрофессиональные клиенты) в противоположность профессиональным клиентам, т.е. солиситорам (англ. professional clients). 
ситора получать свидетельские показания. В настоящее же время этих запретов не существует.

По сути, вышеуказанные реформы должны были привести к выравниванию конкурентоспособности обеих профессий. Фактически это в какой-то степени и произошло, однако принятые меры оказались недостаточными. Адвокатура продолжала ощущать свою «вторичность» на рынке юридических услуг; тревожное настроение относительно будущего не проходило. Хотя традиционно качество подготовки в английской адвокатуре считалось (и считается) высочайшим, как и качество предоставляемых услуг, стоимость которых, во всяком случае по мнению самих барристеров, является относительно невысокой. Тем не менее адвокатура в целом переживала не лучшие дни, что не могло не привести к оттоку кадров (на разных уровнях и из разных областей специализации). Соответственно, назрела необходимость в дальнейших реформах.

Большое количество важных вопросов, связанных с рынком юридических услуг в стране, было разрешено «эпохальным», по выражению барристеров, Законом о юридических услугах 2007 г. (Legal Services Act), принятие которого привело к дальнейшим радикальным изменениям в организации английской адвокатуры.

Профессиональные правила, приведенные в соответствие с вышеуказанным Законом, теперь позволяют барристерам работать в партнерствах (товариществах) друг с другом, участвовать в управлении и владеть акциями/паями структур, называемых Legal Disciplinary Practices (LDPs), одновременно работать в качестве самозанятого лица и по найму (хотя и не по одному и тому же делу), вести деловую переписку в полном объеме от имени клиентов (до этого были существенные ограничения) и т.д.

LDPs представляют собой структуры (как правило, юридические фирмы), в которых среди партнеров - владельцев бизнеса наряду с солиситорами есть другие лица, принадлежащие к юридической профессии (например, барристеры) или вообще не юристы (лиц последней категории должно быть не более $25 \%$ от числа всех партнеров). Статистика свидетельствует о том, что количество фирм, зарегистрировавшихся в качестве LDP и включивших в ряды своих партнеров барристеров, постепенно растет ${ }^{71}$.

Продуктом недавних реформ является также структура под названием ProcureCo, которая является первой корпоративной организационной формой осуществления барристерами своей деятельности. Предполагается, что адвокаты могут создать компанию (владельцем которой может быть и один барристер, и несколько, и даже уже существующие объединения адвокатов - палаты), которая будет предлагать клиентам широкий спектр юридических услуг. Эта компания привлекает на договорной основе прочих специалистов - юри-

71 См.: Шостранд Е. Радикальные реформы в английской адвокатуре // Новая адвокатская газета. 2010. № 23 // <http://www.advgazeta.ru/rubrics/11/582> (последнее посещение - 7 февраля 2012 г.). 
дические фирмы, бухгалтерские/аудиторские фирмы и т.д., - услуги которых используются по мере надобности в различных работах и проектах. Соответственно, при заключении договора на юридическое обслуживание с ProcureCo клиенту гарантируется весь комплекс юридических (и не только) услуг. Представляется, что такая модель прямого сотрудничества с барристерами будет в определенных ситуациях более привлекательной, с точки зрения клиента потребителя услуг, нежели работа с индивидуальным специалистом, юридической фирмой или палатой, особенно при ведении особо сложных, комплексных дел и проектов, где требуются усилия различных специалистов.

Таким образом, хотя в настоящее время и не произошло слияния профессий барристеров и солиситоров, официальное обсуждение вопроса о целесообразности которого в Англии происходило в 80-х годах прошлого века, сама жизнь, существующие экономические условия, побудили законодателя и адвокатское сообщество в этой стране осуществить целый ряд мер, приводящих к существенному сближению данных адвокатских профессий.

Изложенное выше представляло бы интерес лишь в историческом и сравнительно-правовом плане, если бы не появление в среде российских юристов в последнее время высказываний о полезности реформы адвокатской профессии в России, в результате которой произошло бы разделение адвокатов на две категории по английскому типу.

В частности, на выездном заседании коллегии Министерства, состоявшемся 15 июля 2009 г. в Великом Новгороде, министр юстиции РФ Александр Коновалов предложил разделить адвокатов на две категории:

1) адвокатов, которые будут представлять интересы клиентов в суде;

2) стряпчих, которые будут оказывать более простую юридическую помощь.

По мнению А. Коновалова, - это нормальная практика для многих европейских государств. Кроме того, как полагает глава Министерства юстиции России, нужно ужесточить практику работы квалификационных комиссий при адвокатских палатах, ввести профессиональный экзамен для разделения адвокатов и стряпчих. Только адвокатам должно быть предоставлено право участвовать в суде, а стряпчие будут давать консультации клиентам по относительно несложным правовым вопросам ${ }^{72}$.

Положительное отношение к двухуровневой адвокатуре высказывается и некоторыми известными представителями адвокатского сообщества. Так, на вопрос главного редактора журнала «Закон» Я. Пискунова: «Как Вы относитесь к идее разделения адвокатов на консультантов и судебных представителей (по аналогии с солиситорами и барристерами в Великобритании)?» президент адвокатской палаты г. Москвы Г. Резник ответил: «Лично я бы привет-

72 См.: Сборник материалов заседания коллегии Минюста России в Великом Новгороде 15 июля 2009 г. Великий Новгород, 2009. 
ствовал такое разделение. Барристер клиента до процесса не видит. Он имеет дело только с консультантом, который обо всем с клиентом договаривается, ты же абсолютно независим от клиентов, ставки таких гонораров известны, что ограждает тебя от общения с клиентом по этому щекотливому вопросу. Но это, увы, лишь мое пожелание. Оно расходится с нашей действительностью. Разделение на солиситоров и барристеров - специфика Великобритании. У них традиционно всё сложилось именно таким образом» ${ }^{73}$. Хорошей признал идею создания подобной адвокатуры в России, состоящей из адвокатов и стряпчих, также президент Российской гильдии адвокатов Г. Б. Мирзо$\mathrm{eB}^{74}$.

Отвечая на вопрос о том, следует ли допускать в качестве представителей в суд только адвокатов, а для юристов-неадвокатов вход закрыть, бывший председатель Высшего Арбитражного Суда РФ В. Ф. Яковлев, в частности, сказал: «Можно вспомнить английскую адвокатуру, которая имеет два уровня: барристеры и солиситоры. И находиться за судебной перегородкой - баром, отделяющей часть зала, где сидят непосредственные участники судебного процесса (судьи, прокуроры, адвокаты и подсудимые, истцы и ответчики), от публики, - может исключительно барристер. Солиситор же только помогает, работает с гражданами, собирает документы и т.д. Хорошо ли это? На мой взгляд, к такому разделению адвокатских функций можно присмотреться и нам» ${ }^{75}$.

Однако, как показывает вышеприведенный анализ истории российской и западноевропейской, в том числе английской, адвокатуры, введение двухуровневой адвокатуры в России было бы ничем не оправданным шагом назад, отступлением от общего направления развития адвокатуры в цивилизованных странах, определяемого в том числе и условиями современного рынка.

\section{Библиография}

1. Васьковский E. В. Будущее русской адвокатуры: к вопросу о предстоящей реформе. СПб., 1893.

2. Васьковский Е. В. Курс гражданского процесса. Т. 1. М., 1913.

3. Васьковский Е. В. Организация адвокатуры. Ч. 1. СПб., 1893.

4. Васьковский Е. В. Организация адвокатуры. Ч. 2. СПб., 1893.

5. Винавер М. Очерки об адвокатуре. СПб., 1902. С. 115.

6. Гессен И. В. История русской адвокатуры. По изд. 1914 г. Т.1. М., 1997.

7. Карабчевский Н.П. Современная французская адвокатура и новая школа судебного красноречия (по поводу книги Léon Cléry «Souwenirs du Palais») //

73 Резник Г. О проблемах российской адвокатуры // Закон. 2007. № 12. С. 5.

74 См.: Юбилей Гильдии. Интервью с Г. Б. Мирзоевым // Эж-Юрист. 2009. № 38. С. 1.

75 Судебный барьер. Интервью с В. Ф. Яковлевым // Эж-Юрист. 2010. № 16. С. 1. 
Около правосудия: статьи, сообщения и судебные очерки. СПб., 1902. С. 1-42.

8. Макалинский П. В. С.-Петербургская присяжная адвокатура. Деятельность С.-Петербургского совета и общих собраний присяжных поверенных за 22 года (1866-1888 гг.). СПб., 1889.

9. Мальщеев К. Курс гражданского судопроизводства. Т.1. СПб., 1874.

10. Молло М. Правила адвокатской профессии во Франции. По изд. 1894 г. // Традиции адвокатской этики. Избранные труды российских и французских адвокатов (XIX - начало XX вв.) / сост.: И. В. Елисеев, Р. Ю. Панкратов. СПб., 2004.

11. Организация и деятельность адвокатуры в России / Авторысоставители В. М. Ануфриев, С. Н. Гаврилов. М., 2001.

12. Пальховский А. М. О праве представительства на суде. М., 1876. С. $168-169$.

13. Резник Г. О проблемах российской адвокатуры // Закон. 2007. № 12.

14. Сборник материалов заседания коллегии Минюста России в Великом Новгороде 15 июля 2009 г. Великий Новгород, 2009.

15. Судебный барьер. Интервью с В. Ф. Яковлевым // Эж-Юрист. 2010. № 16 .

16. Шостранд Е. Радикальные реформы в английской адвокатуре // Новая адвокатская газета. 2010. № 23.

17. Юбилей Гильдии. Интервью с Г. Б. Мирзоевым // Эж-Юрист. 2009. № 38 .

Материал поступил в редакциию 8 февраля 2012 года 